\title{
UN TRISO Compaction in SiC for FCM Fuel
} Irradiations

\section{Fuel Cycle Research \& Development Advanced Fuels Campaign}

K. Terrani, M. Trammell, J. Kiggans, D. Skitt, B. Jolly Oak Ridge National Laboratory

Prepared for U. S. Department of Energy Office of Nuclear Energy

November 2016 M3FT-17OR020201053 


\section{DISCLAIMER}

This information was prepared as an account of work sponsored by an agency of the U.S. Government. Neither the U.S. Government nor any agency thereof, nor any of their employees, makes any warranty,

expressed or implied, or assumes any legal liability or responsibility for the accuracy, completeness, or usefulness, of any information, apparatus, product, or process disclosed, or represents that its use would not infringe privately owned rights. References herein to any specific commercial product, process, or service by trade name, trade mark, manufacturer, or otherwise, does not necessarily constitute or imply its endorsement, recommendation, or favoring by the U.S. Government or any agency thereof. The views and opinions of authors expressed herein do not necessarily state or reflect those of the U.S. Government or any agency thereof. 


\title{
UN TRISO Compaction in SiC for FCM Fuel Irradiations
}

\author{
K. Terrani, M. Trammell, J. Kiggans, D. Skitt, B. Jolly \\ Oak Ridge National Laboratory
}

November 2016

Prepared by

OAK RIDGE NATIONAL LABORATORY

Oak Ridge, TN 37831-6283

managed by

UT-BATTELLE, LLC

for the

US DEPARTMENT OF ENERGY

under contract DE-AC05-00OR22725 
INTENTIONALLY BLANK 


\section{ABSTRACT}

The U.S. Department of Energy Office of Nuclear Energy (DOE-NE) Advanced Fuels Campaign (AFC) is conducting research and development to elevate the technology readiness level of Fully Ceramic Microencapsulated (FCM) fuels, a candidate nuclear fuel with potentially enhanced accident tolerance due to very high fission product retention. One of the early activities in FY17 was to demonstrate production of FCM pellets with uranium nitride TRISO particles. This was carried out in preparation of the larger pellet production campaign in support of the upcoming irradiation testing of this fuel form at INL's Advanced Test Reactor. 
INTENTIONALLY BLANK 


\section{CONTENTS}

ACKNOWLEDGEMENTS

viii

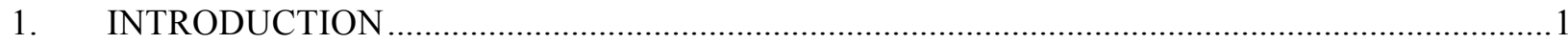

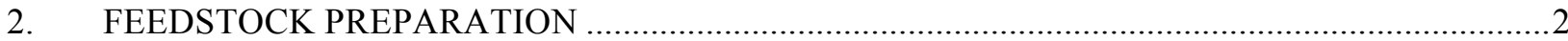

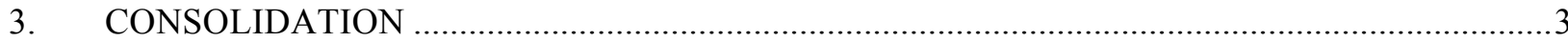

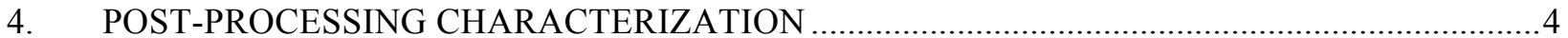

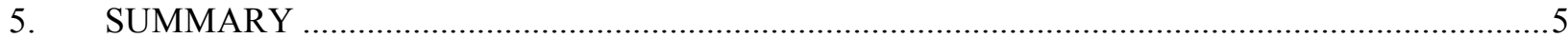

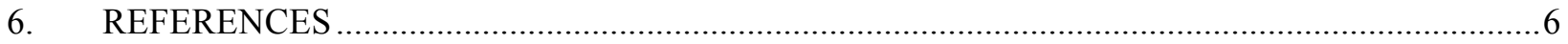

\section{FIGURES}

Figure 1. View inside the SPS chamber prior to UN TRISO FCM pellet consolidation. ............................3

Figure 2. Temperature and displacement profile for UN TRISO FCM pellet production using SPS.

Figure 3. a) optical image of the cross section of the UN TRISO FCM pellet, b) higher magnification image of a few UN TRISO particles inside the dense SiC matrix where no detrimental kernel-coating layer interaction is noted.

\section{TABLES}

Table 1. Dimension and density values for UN TRISO FCM pellet after SPS consolidation. 4 


\section{ACKNOWLEDGEMENTS}

This work was supported by the US Department of Energy Office of Nuclear Energy (DOE-NE) Advanced Fuels Campaign. The authors would like to recognize the thoughtful review of Y. Katoh and N. Brown at Oak Ridge National Laboratory. 


\section{UN TRISO Compaction in SiC for FCM Fuel Irradiations}

\section{INTRODUCTION}

Fully Ceramic Microencapsulated (FCM) fuels consist of tristructural isotropic (TRISO) fuel particles embedded inside a dense sintered $\mathrm{SiC}$ matrix. Multiple barriers to fission product release (various coating layers in the TRISO fuel particle and the SiC matrix) are inherent to this fuel form. Given the excellent oxidation resistance of $\mathrm{SiC}$, this concept is a candidate accident tolerant fuel (ATF) form for potential utilization in LWRs or other advanced reactor concepts. In order to enhance heavy metal loading to achieve sustainable cycle lengths in LWRs, the FCM fuel utilizes uranium nitride kernels instead of oxide or oxide-carbide kernels used previously in HTGR applications. Production of these kernels with appropriate density was undertaken under the auspices of the Advanced Fuels Campaign (AFC) at ORNL in FY 15 and 16 [1]. Coating layer development to produce UN TRISO particles was also completed in FY16 under the AFC program [2].

The focus of this milestone is the consolidation of UN TRISO particles inside a SiC matrix. This process has been codified thanks to significant R\&D support by US DOE Fuel Cycle R\&D program in the past on surrogate TRISO (zirconia instead of uranium-bearing kernels) particles [3,4]. The UN TRISO FCM pellets are to be utilized for irradiation testing. The irradiation is planned at INL's Advanced Test Reactor (ATR). This is a critical step in development of this fuel concept to establish the ability of this fuel to retain fission products under prototypical irradiation conditions. This paper reports the first set of results on UN TRISO FM pellet fabrication and characterization. 


\section{FEEDSTOCK PREPARATION}

The UN TRISO particles were taken from the FCM-4A-UN31K-02T batch prepared previously (details of production and characterization is available in ref. [2]). For SiC powder feedstock a slurry was initially prepared, consisting of $80 \mathrm{~nm} \mathrm{SiC} \mathrm{powder} \mathrm{(Nanomakers,} \mathrm{France,} \mathrm{Lot \#} \mathrm{12-SiC-122),} \mathrm{thoroughly} \mathrm{mixed}$ with $6 \mathrm{wt} \%$ yttria-alumina as sintering aides suspended in ethanol. The alumina and yttria were added at a constant mass ratio of 3.9:2.1 $\mathrm{Al}_{2} \mathrm{O}_{3}: \mathrm{Y}_{2} \mathrm{O}_{3}$. The final concentration of the $\mathrm{SiC}$ powder sintering aide mixture was $0.15 \mathrm{~g}$ powder per $\mathrm{ml}$ of slurry.

The particles and slurry were moved into a designated nano-coating hood. The coating apparatus has been described in previous publications [3,5], and consists of a custom rotating chamber that is heated by a hot air blower. Particles rotating in the chamber are coated using an ultrasonic generator atomizing nozzle, with the slurry pumped by a peristaltic pump. The slurry was sprayed at approximately 1 to $1.3 \mathrm{ml}$ per minute. The coating process was interrupted three times to weigh particles to estimate progress in coating. The final weight of the coated particles was $41.09 \mathrm{~g}$ to give a coating to particle ratio of approximately 1.05 . Since the FCM-4A-UN31K-02T TRISO particles is $4.95 \mathrm{~g} / \mathrm{cm}^{3}$ and the density of the $\mathrm{SiC}$ matrix is $3.19 \mathrm{~g} / \mathrm{cm}^{3}$, this results in a pellet with a particle packing fraction of $38 \mathrm{vol} \%$. 


\section{CONSOLIDATION}

The standard configuration for FCM pellet consolidation consisting of a graphite sleeve placed inside a graphite die was used during sintering. A $44 \mathrm{~mm}$ long tube of fine $\mathrm{SiC}$ braid was placed inside the sleeve to act as the $\mathrm{SiC}$ surface buffer as discussed elsewhere [3]. SiC powder feedstock at $0.40 \mathrm{~g}$ without any particles was poured into the die at the top and bottom of the coated particle stack. $3.03 \mathrm{~g}$ of coated particles were placed inside the die and the entire mixture was cold-pressed at $\sim 445 \mathrm{~N}$ of force.

The die was then placed inside a spark plasma sintering unit, SPS Model 25-10 (Thermal Technology, Santa Rosa, CA), Figure 1. The SPS run was conducted at $10 \mathrm{MPa}$ pressure for the preload and during the run. An initial ramp rate of $150^{\circ} \mathrm{C} / \mathrm{min}$ to $400^{\circ} \mathrm{C}$ followed by a ramp rate of $100^{\circ} \mathrm{C} / \mathrm{min}$ to $1825^{\circ} \mathrm{C}$ was utilized followed by a 5 min hold at maximum temperature, Figure 2.

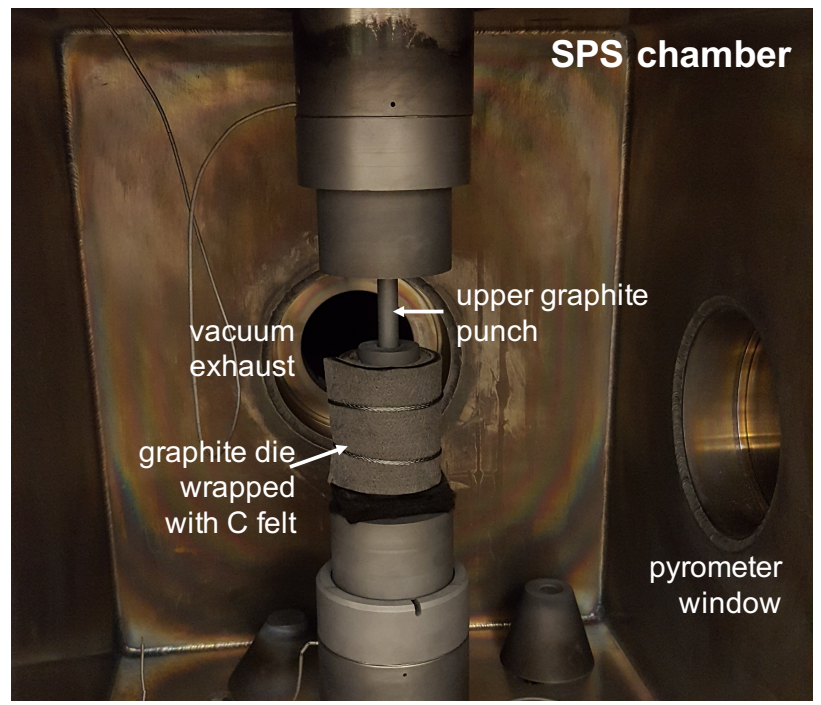

Figure 1. View inside the SPS chamber prior to UN TRISO FCM pellet consolidation.

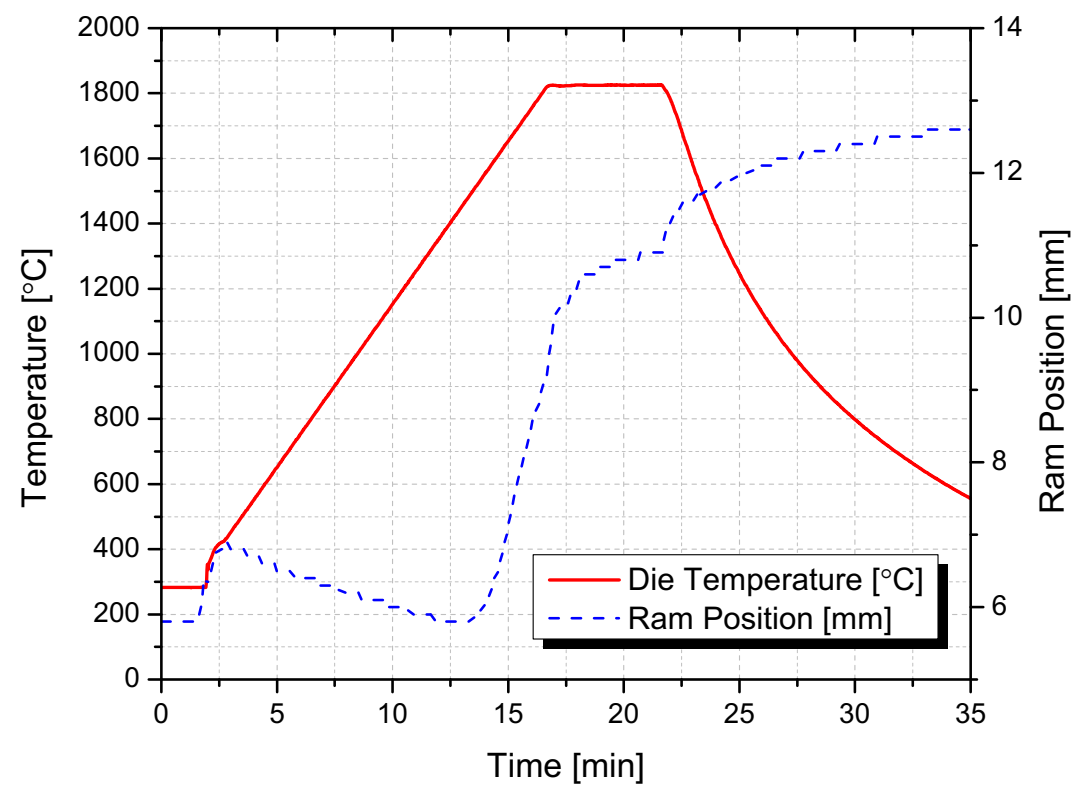

Figure 2. Temperature and displacement profile for UN TRISO FCM pellet production using SPS. 


\section{POST-PROCESSING CHARACTERIZATION}

After completion of the SPS consolidation process, the UN TRISO FCM pellet was removed from the die and underwent dimensional inspection, the results of which are reported in Table 1. The pellet was subsequently axially cross sectioned and prepared for metallographic examination. Figure 3 shows the optical images of the pellet cross sections. Prior to polishing the cross section was back potted with epoxy to infiltrate the coating layers of the particles and keep them in place during the polishing process. After polishing some back potting remnants were still present on the surface (additional polishing will remove those remnant epoxy sections). The pellet exhibits a dense matrix and no detrimental particle-particle interaction was observed, indicative of an effective overcoating process. Furthermore, the UN kernels did not show any signs of degradation or interaction with the carbon buffer layer after $1825^{\circ} \mathrm{C}$ SPS consolidation step.

Table 1. Dimension and density values for UN TRISO FCM pellet after SPS consolidation.

\begin{tabular}{|c|c|c|}
\hline Parameter & Value & Average \\
\hline Height $1[\mathrm{~mm}]$ & 9.555 & \\
\hline Height $2[\mathrm{~mm}]$ & 9.470 & 9.542 \\
\hline Height $3[\mathrm{~mm}]$ & 9.602 & \\
\hline Diameter $1[\mathrm{~mm}]$ & 12.929 & \\
\hline Diameter $2[\mathrm{~mm}]$ & 12.948 & 12.907 \\
\hline Diameter $3[\mathrm{~mm}]$ & 12.844 & \\
\hline Pellet Mass [g] & & \\
\hline Pellet Volume $\left[\mathrm{cm}^{3}\right]$ & & \\
\hline Pellet Density $\left[\mathrm{g} / \mathrm{cm}^{3}\right]$ & & \\
\hline
\end{tabular}
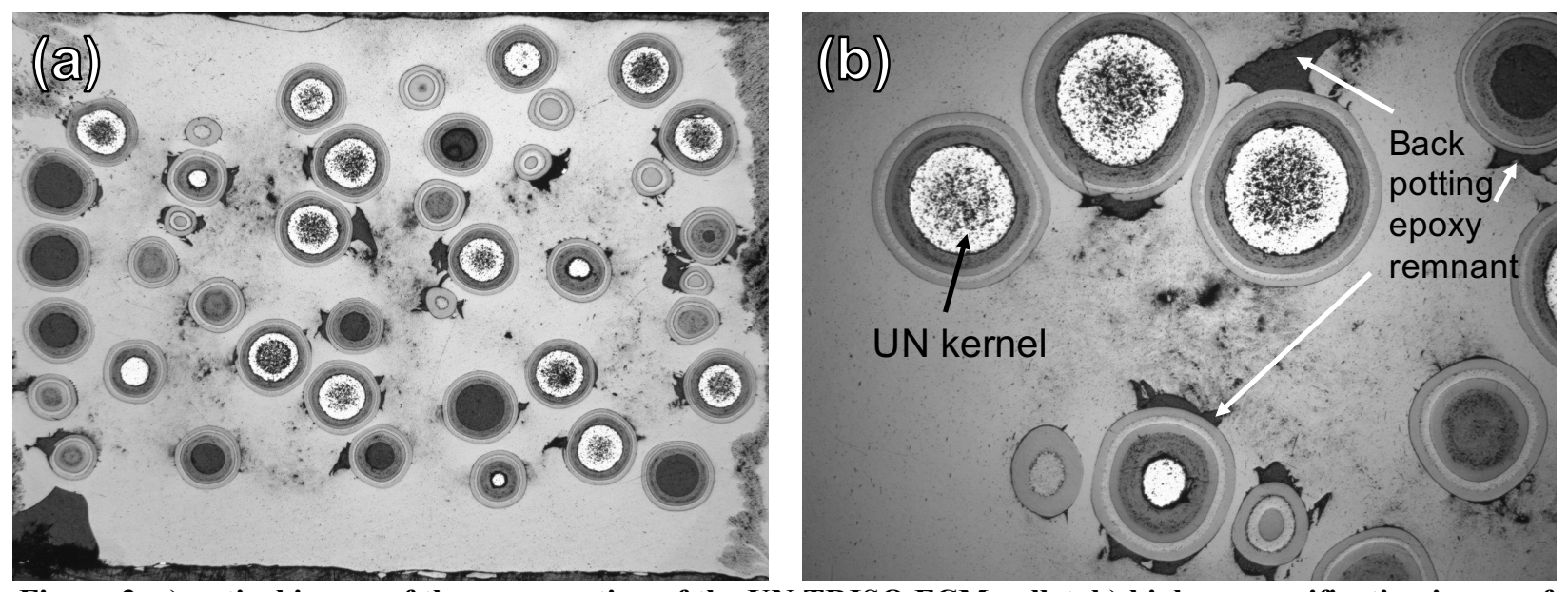

Figure 3. a) optical image of the cross section of the UN TRISO FCM pellet, b) higher magnification image of a few UN TRISO particles inside the dense SiC matrix where no detrimental kernel-coating layer interaction is noted. 


\section{SUMMARY}

UN TRISO pellet production was undertaken in support of upcoming ATR irradiation of FCM fuel form and in order to continue its development and elevate its technology readiness level. This report demonstrates, for the first time, production of FCM pellets with LWR-application-optimized UN TRISO particles. SPS consolidation was utilized that yielded a dense SiC matrix around UN TRISO particles without any detrimental particle-particle interaction after this step. Also, no degradation of UN kernel inside the TRISO particle was noted. 


\section{REFERENCES}

[1] T.B. Lindemer, C.M. Silva, J.J. Henry, J.W. McMurray, S.L. Voit, J.L. Collins, et al., Quantification of process variables for carbothermic synthesis of UC 1-x N x fuel microspheres, J. Nucl. Mater. 483 (2017) 176-191.

[2] B. Jolly, G. Helmreich, J. Dyer, K. Terrani, FABRICATION AND CHARACTERIZATION OF DU and LEU UN TRISO PARTICLES, ORNL/LTR-2016/384, M3FT-16OR020201062, 2016.

[3] K.A. Terrani, J.O. Kiggans, C.M. Silva, C. Shih, Y. Katoh, L.L. Snead, Progress on matrix SiC processing and properties for fully ceramic microencapsulated fuel form, J. Nucl. Mater. 457 (2015) 9-17. doi:10.1016/j.jnucmat.2014.10.034.

[4] K. Terrani, M. Trammell, J. Kiggans, C. Ang, Studies on Alternative or Optimized Processing Techniques Leading to FCM Fuel Mass Production, ORNL/TM-2016/366, M3FT16OR020201064, 2016.

[5] P.J. Pappano, T.D. Burchell, J.D. Hunn, M.P. Trammell, A novel approach to fabricating fuel compacts for the next generation nuclear plant (NGNP), J. Nucl. Mater. 381 (2008) 25-38. doi:10.1016/j.jnucmat.2008.07.032. 